Int. J. Electrochem. Sci., 12 (2017) $7446-7456$

International Journal of

ELECTROCHEMICAL

SCIENCE

WWW.electrochemsci.org

\title{
Determination of Non-Steroidal Anti-Inflammatory Drug (NSAID) Azathioprine in Human Blood Serum and Tablet Samples Using Multi-Walled Carbon Nanotubes (MWCNTs) Decorated Manganese Oxide Microcubes Composite Film Modified Electrode
}

\author{
Akilarasan Muthumariappan ${ }^{1}$, Mani Govindasamy ${ }^{1}$, Shen-Ming Chen ${ }^{1,}{ }^{*}$, Kogularasu Sakthivel ${ }^{1}$, \\ Veerappan Mani ${ }^{1,2}$ Tse-Wei Chen $^{1}$, Shanthi Selvaraj ${ }^{3,4}$ \\ ${ }^{1}$ Department of Chemical Engineering and Biotechnology, National Taipei University of Technology, \\ Taipei, Taiwan 106 (ROC) \\ ${ }^{2}$ Graduate Institute of Biomedical and Biochemical Engineering, National Taipei University of \\ Technology, Taipei, Taiwan 106 (ROC) \\ ${ }^{3}$ Research Institute of Electronics, Shizuoka University, Japan \\ ${ }^{4}$ Department of Physics and Nanotechnology, SRM University, India \\ *E-mail: smchen78@ms15.hinet.net
}

doi: $10.20964 / 2017.08 .145$

Received: 10 May 2017 / Accepted: 14 June 2017 / Published: 12 July 2017

The development of sensor for azathioprine (ATP) determination is extremely important as its excess level in blood imposes carcinogenic threats. A sensitive, selective, reproducible and durable azathioprine sensor was demonstrated using a nanocomposite composed of $\mathrm{Mn}_{3} \mathrm{O}_{4}$ micro cubes and multi-walled carbon nanotubes (MWCNTs/ $\mathrm{Mn}_{3} \mathrm{O}_{4} \mathrm{MCs}$ ). The composite was prepared through a facile hydrothermal method and its morphology, elemental, impedance and electrochemical properties were studied. The MWCNTs $/ \mathrm{Mn}_{3} \mathrm{O}_{4} \mathrm{MCs}$ was modified on the screen-printed electrode, and the resulting modified electrode displayed excellent electrocatalytic ability towards ATP and the reduction peak current was related to the concentration of ATP. The working range was $0.045-2530 \mu \mathrm{M}$ and the detection limit was $4.3 \mathrm{nM}( \pm 2.53)$. The method was successfully applied to the determination of ATP in spiked samples of human blood serum and tablets.

Keywords: Analytical Science; Multi-walled carbon nanotubes; Hybrid materials; Manganese oxide; Modified electrode; Signal amplification; Biochemistry.

$\underline{\text { FULL TEXT }}$ 
(C) 2017 The Authors. Published by ESG (www.electrochemsci.org). This article is an open access article distributed under the terms and conditions of the Creative Commons Attribution license (http://creativecommons.org/licenses/by/4.0/). 